\title{
Analysis of Life-Course Factors Influencing Growth and Development in Children under 3 Years Old of Early Marriage Women in Kediri
}

\author{
Umianita Risca Wulandari'1), Uki Retno Budihastuti²), Eti Poncorini Pamungkasari3) \\ 1) Masters Program in Public Heath, Sebelas Maret University, Surakarta \\ 2) Department of Obstetrics and Ginecology, Dr. Moewardi Hospital, Surakarta \\ 3) Faculty of Medicine, Sebelas Maret University, Surakarta
}

\begin{abstract}
Background: Children is the future pillar of our nation. As such, children need is important to be fulfilled. Physical, mental, and emotional conditions of mothers during gestation period play an important role in growth and development of children. This study aimed to determine life-course factors influencing growth and development in children under 3 years old of early marriage women.

Subjects dan Method: This was an analytic observational study with retrospective cohort design. This study was conducted at Sukorame and Campurejo Health Center, Kediri, East Java, on March, 2017. A sample of 120 children under 3 years old were selected for this study by fixed exposure sampling. The dependent variable was child growth (weight for age) and development. The independent variables were marital age, maternal mid upper arm circumference (MUAC) during pregnancy, gestational age of birth delivery, family stimulation, maternal education, and family income. The data of child weight were measured by scales and recorded in maternal and child health book. The data of other variables were measured by a set of questionnaire. The data were analyzed by path analysis.

Results: Child growth (weight for age) was affected by birthweight $(b=0.07 ; \mathrm{SE}=0.02 ; \mathrm{p}<0.001)$ and family income $(b=0.04 ; \mathrm{SE}=0.02 ; \mathrm{p}=0.07)$. Birthweight was affected by maternal education $(b=2.11 ; S E=1.83 ; p=0.248)$, gestational age of birth $(b=0.67 ; S E=0.22 ; p=0.002)$, maternal MUAC $(b=1.46 ; S E=0.24 ; p=0.002)$, and family income $(b=0.22 ; S E=0.09, p=0.012)$. Family income was affected by marital age $(b=0.68 ; \mathrm{SE}=0.073 ; \mathrm{p}<0.001)$. Maternal MUAC during pregnancy was affected by marital age $(b=0.12, S E=0.03, p<0.001)$. Maternal education was affected by marital age $(b=0.01 ; S E=0.001 ; p=0.002)$. Family stimulation was affected by family income $(b=0.75, \mathrm{SE}=0.26, \mathrm{p}=0.003)$. Child development was affected by marital age $(b=0.07$, $\mathrm{SE}=0.02, \mathrm{p}=0.001)$, family stimulation $(\mathrm{b}=0.02 ; \mathrm{SE}=0.01 ; \mathrm{p}<0.001)$, and birthweight $(\mathrm{b}<0.001$; $\mathrm{SE}<0.001 ; \mathrm{p}=0.373)$.

Conclusion: Child growth of under 3 years old (weight for age) is directly affected by birthweight and family income, and indirectly affected by some other factors. Child development is directly affected by marital age, family stimulation, and birthweight, and indirectly affected by some other factors.
\end{abstract}

Keywords: life-course, growth, development, children under 3 years old

Correspondence:

Umianita Risca Wulandari. Masters Program in Public Heath, Sebelas Maret University, Surakarta. Email: umianita03@gmail.com. Mobile:+6285736404487.

\section{LATAR BELAKANG}

Pertumbuhan dan perkembangan anak sangat penting karena akan menjadi dasar kualitas generasi penerus bangsa (Kemenkes RI, 2014). Diperlukan pemenuhan kebutuhan dasar untuk mencapai perkembangan yang optimal. Salah satu hal yang harus dipenuhi adalah kondisi fisik, mental dan emosional ibu yang matang yang dapat 
Journal of Maternal and Child Health (2017), 2(2): 137-149

https://doi.org/10.26911/thejmch.2017.02.02.05

dilihat dari usia ibu saat menikah dan hamil (Depkes RI, 2016).

Sebanyak lebih dari 700 juta perempuan menikah sebelum usia 18 tahun di seluruh dunia. Jumlah tersebut mewakili sekitar 25\% dari jumlah perkawinan usia anak secara global (UNICEF, 2016). Pelaku perkawinan usia anak di wilayah ASEAN, negara Indonesia menempati urutan kedua setelah Kamboja. Angka pernikahan usia dini di Provinsi Jawa Timur mencapai 39\% atau lebih tinggi dari rata-rata nasional (Riset Kesehatan Dasar, 2013). Angka pernikahan usia dini di Kota Kediri pada tahun 2013 sebanyak 297, tahun 2014 sebanyak 224 dan tahun 2015 sebanyak 184. Jumlah pernikahan usia dini terbanyak di Kecamatan Mojoroto, Kota Kediri yaitu sebanyak 747 dalam periode 5 tahun terakhir.

Fakta lain yang berkaitan dengan pertumbuhan anak adalah berat bayi lahir rendah. Jumlah kelahiran dengan BBLR di kota Kediri pada tahun 2015 sebanyak 110 bayi (2.6\%). Jumlah tersebut mengalami penurunan dibandingkan pada tahun 2014 yaitu sebanyak 117 bayi. Kelahiran bayi dengan BBLR harus menjadi perhatian khusus. Kondisi tersebut berkaitan dengan penyebab kematian neonatus (bayi usia o28 hari) di kota Kediri sebagian besar (56.25\%) disebabkan oleh BBLR (Dinkes Kota Kediri, 2016).

Kondisi psikologis ibu yang berkaitan dengan usiad an status gizi saat hamil (ukuran lingkar lengan atas), berat badan lahir, stimulasi keluarga dan kondisi sosio ekonomi dapat mempengaruhi pertumbuhan dan perkembangan anak (Depkes RI, 2006).

Wanita yang menikah dibawah usia 18 tahun atau lebih dikenal dengan pernikahan usia dini cenderung akan mengalami kehamilan dan persalinan di bawah usia reproduksi sehat. Hal tersebut akan meningkatkan risiko melahirkan dengan kon-

disi berat bayi lahir rendah. Kehamilan pada usia dini berkaitan dengan kondisi organ reproduksi ibu yang belum matang. Kehamilan yang mampu bertahan pada ibu yang berusia kurang dari 20 tahun memiliki kemungkinan lebih besar untuk melahirkan bayi dengan berat badan lahir rendah dan mengalami masalah nutrisi dan gangguan pada perkembangan kognitifnya (UNICEF, 2016).

Wanita yang mengalami pernikahan usia dini cenderung memiliki pendidikan yang rendah dan secara psikologis belum siap memberikan kontribusi terhadap keluarga termasuk tumbuh kembang anaknya (Badan Pusat Statistik, 2016). Pelaku pernikahan usia dini juga memiliki tingkat stress yang tinggi yang secara tidak langsung akan berpengaruh terhadap kondisi kehamilannya (Mena, 2016).

Anak yang dilahirkan oleh wanita usia remaja akan mempunyai tingkat kecerdasan yang lebih rendah bila dibandingkan dengan anak yang dilahirkan dari ibu yang berusia lebih dewasa. Penyebabnya adalah ibu belum mampu memberikan stimulasi yang optimal terhadap anak - anak mereka (UNICEF, 2014). Anak yang lahir dari ibu yang berusia di bawah umur membutuhkan pendampingan khusus dari tenaga kesehatan dan stimulasi tumbuh kembang yang baik untuk menunjang kulitas hidupnya.

Mengingat risiko tumbuh kembang yang tidak optimal dari anak yang lahir dari ibu yang menikah usia dini, diharapkan seluruh pihak terkait mampu meningkatkan rasa peduli terhadap pelaku pernikahan usia dini terutama terkait dengan tumbuh kembang anaknya. Tujuan penelitian ini adalah menganalisis faktor sepanjang hayat yang mempengaruhi partumbuhan dan perkembangan anak batita dari ibu yang menikah usia dini di kota Kediri. 


\section{SUBJEK DAN METODE \\ 1. Desain Penelitian \\ Penelitian ini merupakan analitik obser- vasional dengan pendekatan kohor retro- spektif. Penelitian ini dilaksanakan di Keca- matan Mojoroto, Kota Kediri yang meliputi wilayah kerja Puskesmas Sukorame dan Puskesmas Campurejo. Penelitian dilaksa- nakan pada bulan Mei 2017.}

\section{Populasi dan Sampel}

Populasi dalam penelitian ini adalah seluruh batita yang berada di Kecamatan Mojoroto, Kota Kediri, Jawa Timur yang lahir dari ibu yang menikah usia $<16$ tahun atau $\geq 16$ tahun. Subjek penelitian sebesar 120 batita. Teknik sampling yang digunakan yaitu fixed exposure sampling.

\section{Variabel Penelitian}

Variabel dependen yaitu pertumbuhan dan perkembangan batita. Variabel independen yaitu usia ibu saat menikah, LILA ibu saat hamil, berat badan bayi lahir, umur kehamilan saat bayi lahir, stimulasi keluarga, pendidikan ibu dan pendapatan keluarga.

\section{Definisi Operasional}

Definisi operasional variabel LILA saat hamil adalah salah satu indikator status gizi ibu hamil yang diukur melalui lingkar lengan atas ibu hamil dengan pita pengukur LILA.

Definisi operasional berat badan lahir adalah berat bayi yang ditimbang pada saat baru lahir. Umur kehamilan adalah usia kehamilan pada saat bayi dilahirkan yang dihitung berdasarkan hari pertama haid terakhir. Stimulasi keluarga adalah segala bentuk rangsangan yang dilakukan oleh $\mathrm{ibu/pengasuh/orang} \mathrm{terdekat} \mathrm{anak} \mathrm{yang}$ terkait dengan pertumbuhan dan perkembangannya.

Pendidikan ibu adalah strata pendidikan yang ditetapkan berdasarkan peringkat perkembangan peserta didik. Pendapatan keluarga adalah penghasilan keluarga sebagai sumber ekonomi yang diterima selama satu bulan.

Pertumbuhan batita adalah bertambahnya ukuran fisik anak yang dapat dilihat dari ukuran berat badan menurut umur anak. Perkembangan batita adalah perkembangan anak yang meliputi motorik kasar, motorik halus, bicara dan bahasa serta sosialisasi dan kemandirian.

\section{Instrumen Penelitian}

Data untuk mengetahui berat badan bayi diperoleh menggunakan timbangan berat badan bayi. Data tentang LILA ibu saat hamil, berat badan lahir bayi dan usia kehamilan saat bayi lahir dikumpulkan menggunakan buku KIA. Data usia ibu saat menikah, stimulasi keluarga, pendapatan keluarga, pendidikan dan perkembangan anak batita dikumpulkan menggunakan kuesioner.

\section{Analisis Data}

Data dianalisis menggunakan analisis jalur dengan AMOS 20. Tahap analisis data menggunakan analisis jalur AMOS yaitu:

1. Spesifikasi model

2. Identifikasi model

3. Estimasi

4. Model fit

5. Respesifikasi model 
Journal of Maternal and Child Health (2017), 2(2): 137-149

https://doi.org/10.26911/thejmch.2017.02.02.05

badan $\geq 2,500$ gram sebanyak $60.8 \%$. Sebanyak $87.5 \%$ batita lahir dengan usia kehamilan $\geq 37$ minggu. Batita yang mendapatkan stimulasi yang baik dari keluarga sebanyak $87.5 \%$. Ibu yang mempunyai tingkat pendidikan tinggi sebanyak $65 \%$.
Sebagian besar batita berasal dari keluarga dengan pendapatan tinggi (65\%). Sebagian besar batita mempunyai status gizi baik (83.3\%) dan perkembangan anak yang sesuai (92.5\%).

Tabel 1. Karakteristik subjek penelitian

\begin{tabular}{|c|c|c|c|}
\hline Karakteristik & Kriteria & $\mathbf{N}$ & $\%$ \\
\hline \multirow[t]{2}{*}{ Jenis Kelamin } & Laki - Laki & 54 & 45 \\
\hline & Perempuan & 66 & 55 \\
\hline \multirow[t]{2}{*}{ Usia Menikah } & $<16$ tahun & 40 & $33 \cdot 3$ \\
\hline & $\geq 16$ tahun & 80 & 66.7 \\
\hline \multirow[t]{2}{*}{ LILA saat hamil } & $<23.5 \mathrm{~cm}$ & 34 & 28.3 \\
\hline & $\geq 23.5 \mathrm{~cm}$ & 86 & 71.7 \\
\hline \multirow[t]{2}{*}{ Berat Badan Lahir } & $<2,500$ gram & 47 & 47 \\
\hline & $\geq 2,500$ gram & 73 & 73 \\
\hline \multirow[t]{2}{*}{ Usia Kehamilan saat lahir } & $<37$ minggu & 15 & 12.5 \\
\hline & $\geq 37$ minggu & 105 & 87.5 \\
\hline \multirow[t]{2}{*}{ Stimulasi Keluarga } & Kurang & 15 & 12.5 \\
\hline & Baik & 105 & 87.5 \\
\hline \multirow[t]{2}{*}{ Pendidikan Ibu } & Tinggi & 78 & 65 \\
\hline & Rendah & 42 & 35 \\
\hline \multirow[t]{2}{*}{ Pendapatan Keluarga } & $<\operatorname{Rp~1,494,000}$ & 42 & 42 \\
\hline & $\geq \operatorname{Rp} 1,494,000$ & 78 & 78 \\
\hline \multirow[t]{4}{*}{ Pertumbuhan Batita } & Gizi Buruk & o & o \\
\hline & Gizi Kurang & 20 & 16.7 \\
\hline & Gizi Baik & 100 & $83 \cdot 3$ \\
\hline & Gizi Lebih & 0 & 0 \\
\hline \multirow[t]{2}{*}{ Perkembangan Batita } & Sesuai & 111 & 92.5 \\
\hline & Penyimpangan & 9 & 7.5 \\
\hline
\end{tabular}

Hasil statistik deskriptif data kontinu yang berupa usia ibu saat menikah, lingkar lengan atas ibu saat hamil, berat badan bayi lahir, usia kehamilan saat bayi lahir, sti- mulasi keluarga, pendidikan ibu, pendapatan keluarga, pertumbuhan dan perkembangan batita dapat dilihat pada Tabel 2 .

Tabel 2. Analisis univariat variabel penelitian

\begin{tabular}{lccccc}
\hline \multicolumn{1}{c}{ Variabel } & n & Mean & SD & Min. & Maks. \\
\hline Usia menikah ibu & 120 & 19.69 & 4.07 & 14 & 28 \\
Lingkar lengan atas saat hamil & 120 & 23.79 & 1,56 & 20 & 27 \\
Berat badan lahir & 120 & 27.02 & 4.93 & 20 & 40 \\
Usia kehamilan saat lahir & 120 & 39.00 & 1.67 & 34 & 41 \\
Stimulasi keluarga & 120 & 77.17 & 12.32 & 45 & 88 \\
Pendidikan ibu & 120 & 0.96 & 0,20 & 0 & 1 \\
Pendapatan Keluarga & 120 & 15.93 & 4.28 & 90 & 350 \\
Pertumbuhan & 120 & -0.32 & 1.09 & -2.98 & 0.89 \\
Perkembangan & 120 & 9.09 & 0,99 & 6 & 10 \\
\hline
\end{tabular}

Tabel 2 menunjukkan bahwa masingmasing variabel memiliki keberagaman data yang relatif kecil. Mean menggambarkan nilai rata-rata, sedangkan nilai stan- dard deviation (SD) menggambarkan seberapa jauh bervariasinya data. Nilai SD yang kecil mengindikasikan data representative. 
Tabel 3. Analisis bivariat faktor yang mempengaruhi pertumbuhan dan perkembangan anak batita dari ibu yang menikah usia dini

\begin{tabular}{lcccc}
\hline \multicolumn{1}{c}{ Variabel Independen } & \multicolumn{2}{c}{ Pertumbuhan } & \multicolumn{2}{c}{ Perkembangan } \\
& $\mathbf{r}$ & $\mathbf{p}$ & $\mathbf{r}$ & $\mathbf{p}$ \\
\hline Usia ibu saat menikah (tahun) & 0.30 & 0.001 & 0.28 & 0.002 \\
LILA ibu atas saat hamil (cm) & 0.16 & 0.070 & 0.003 & 0.974 \\
Berat badan bayi lahir (gram) & 0.37 & $<0.001$ & 0.05 & 0.629 \\
Usia kehamilan saat lahir (minggu) & 0.09 & 0.287 & 0.43 & 0.638 \\
Stimulasi keluarga & 0.07 & 0.425 & 0.19 & 0.039 \\
Pendidikan ibu & 0.41 & $<0.001$ & 0.16 & 0.078 \\
Pendapatan Keluarga (Rupiah) & 0.27 & 0.003 & 0.22 & 0.012 \\
Pertumbuhan batita & 0.31 & 0.74 & 0.31 & 0.739 \\
Perkembangan batita & 0.31 & 0.74 & 0.31 & 0.739 \\
\hline
\end{tabular}

Tabel 3 menunjukkan bahwa usia menikah ibu ( $\mathrm{r}=0.30 ; \mathrm{p}=0,001)$, lingkar lengan atas saat hamil $(\mathrm{r}=0.16 ; \mathrm{p}=0.07)$, berat badan lahir $(\mathrm{r}=0.37 ; \mathrm{p}<0.001)$, pendidikan ibu $(\mathrm{r}=0.41 ; \mathrm{p}<0.001)$, pendapatan keluarga $(\mathrm{r}=0.27, \mathrm{p}=0.003)$ memiliki pengaruh positif terhadap pertumbuhan batita dan secara statistik signifikan. Usia menikah ibu $(\mathrm{r}=$ $0.28, \mathrm{p}=0.002)$, stimulasi keluarga $(\mathrm{r}=0.19$, $\mathrm{p}=0.029)$, pendapatan keluarga $(\mathrm{r}=0.16$, $\mathrm{p}=0.012)$ memiliki pengaruh positif terhadap perkembangan anak batita dan secara statistik signifikan.

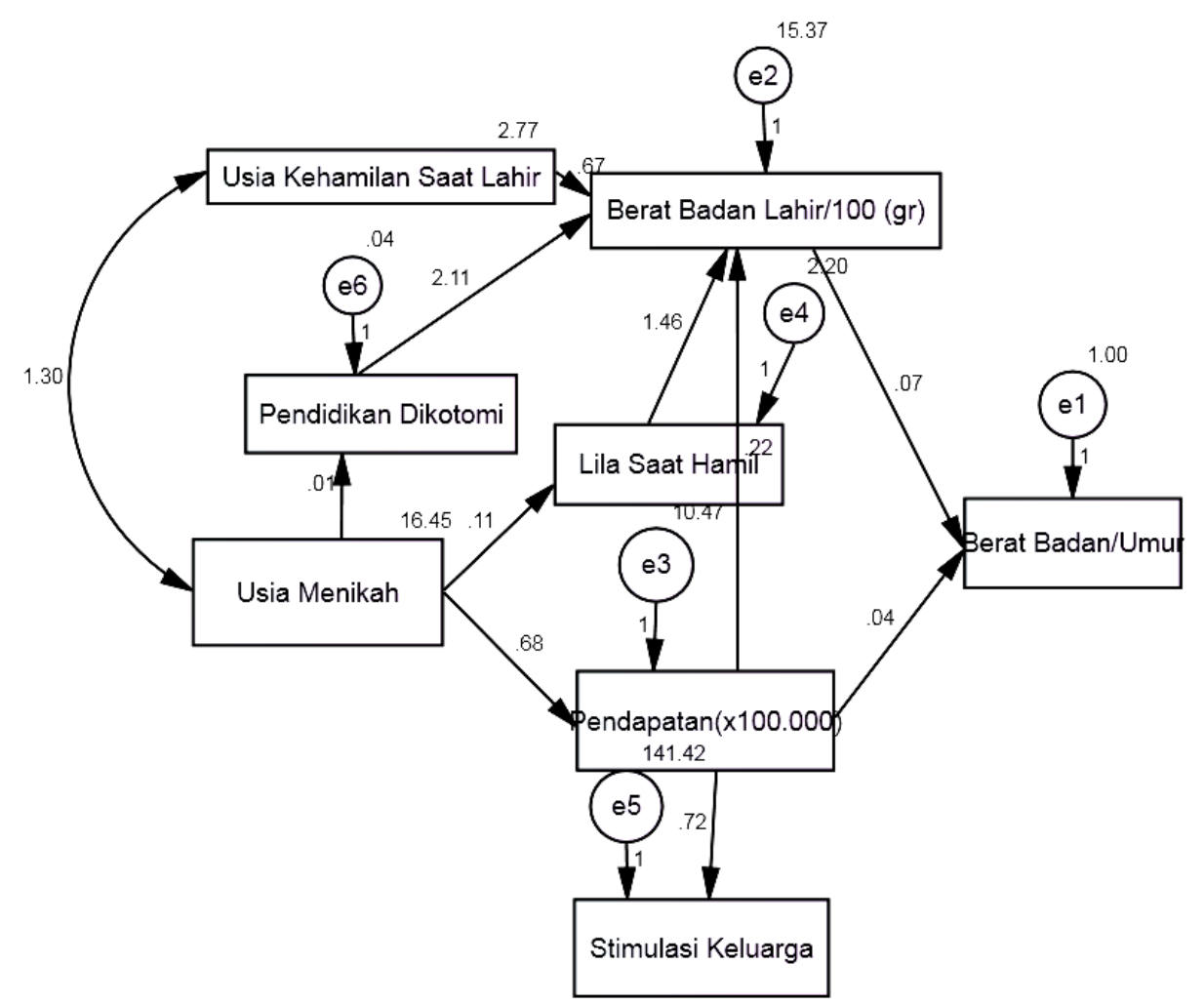

Gambar 1. Model struktural analisis jalur variabel pertumbuhan

Gambar 1 menunjukkan model struktural setelah dilakukan estimasi menggunakan IBM SPSS AMOS 20, sehingga didapat- kan nilai seperti pada gambar tersebut. Indikator yang menunjukan kesesuaian model analisis jalur pada Tabel 4 juga me 
Journal of Maternal and Child Health (2017), 2(2): 137-149

https://doi.org/10.26911/thejmch.2017.02.02.05

nunjukkan adanya goodness of fit measure (pengukuran kecocokan model) bahwa didapatkan hasil fit index (indeks kecocokan) CMIN sebesar 8.78 dengan $\mathrm{p}=0.947$ $(>0.05) ; \quad \mathrm{NFI}=0.95 \quad(\geq 0.90) ; \quad \mathrm{CFI}=1.00$

Tabel 4. Hasil analisis jalur variabel pertumbuhan

\begin{tabular}{|c|c|c|c|c|c|c|}
\hline Variabel Endogen & & Variabel Eksogen & $\mathbf{b}^{*}$ & SE & $\mathbf{p}$ & $\boldsymbol{\beta}^{* *}$ \\
\hline \multicolumn{7}{|l|}{ Pengaruh Langsung } \\
\hline Pertumbuhan & $\leftarrow$ & Pendapatan (x Rp 100,000) & 0.04 & 0.02 & 0.062 & 0.16 \\
\hline Pertumbuhan & $\leftarrow$ & Berat Lahir (x 100 gram) & 0.07 & 0.02 & $<0.001$ & 0.33 \\
\hline \multicolumn{7}{|l|}{ Pengaruh Tidak Langsung } \\
\hline Berat lahir (x 100 gram) & $\leftarrow$ & Pendidikan $\geq$ SMA & 2.11 & 1.83 & 0.248 & 0.09 \\
\hline Berat lahir (x 100 gram) & $\leftarrow$ & Usia Kehamilan (minggu) & 0.67 & 0.22 & 0.002 & 0.22 \\
\hline Berat la & $\leftarrow$ & Pendapatan (x Rp 100,000) & 0.22 & 0.09 & 0.012 & 0.19 \\
\hline Berat lahir (x 10o gram) & $\leftarrow$ & LILA saat hamil $(\mathrm{cm})$ & 1.46 & 0.24 & $<0.001$ & 0.46 \\
\hline Pendidikan $\geq$ SMA & $\leftarrow$ & Usia ibu menikah ( tahun) & 0.01 & $<0.01$ & 0.002 & 0.27 \\
\hline LILA ibu hamil (cm) & $\leftarrow$ & Usia ibu menikah (tahun) & 0.12 & 0.03 & $<0.001$ & 0.30 \\
\hline Pendapatan (xRp 100,000) & $\leftarrow$ & Usia ibu menikah (tahun) & 0.68 & 0.07 & $<0.001$ & 0.65 \\
\hline Stimulasi Keluarga & $\leftarrow$ & Pendapatan (x Rp 100,000) & 0.72 & 0.26 & 0.005 & 0.25 \\
\hline
\end{tabular}

Model Fit
( $\geq 0.95)$; RMSEA<0.001 $(\leq 0.08)$ yang berarti model empirik tersebut memenuhi kriteria yang ditentukan dan dinyatakan sesuai dengan data empirik.

$$
\begin{array}{lll}
\text { CMIN } & =8.78 & \mathrm{p}=0.947(>0.05) \\
\text { NFI } & =0.95 & (\geq 0.90) \\
\text { CFI } & =1.00 & (\geq 0.95) \\
\text { RMSEA } & =0.00 & (\leq 0.08)
\end{array}
$$

**: koefisien jalur terstandarisasi

berat badan bayi lahir sebesar 67 unit $(\mathrm{b}=$ $0.67 ; \mathrm{SE}=0.22 ; \mathrm{p}=0.002$ ).

Setiap satu unit peningkatan pendapatan keluarga (x Rp 100,000) akan meningkatkan berat badan lahir sebesar 2.11 unit $(b=2.11 ; \mathrm{SE}=1.83 ; \mathrm{p}=0.248)$.

Setiap peningkatan satu unit LILA ibu saat hamil $(\mathrm{cm})$ akan meningkatkan berat bayi lahir sebesar 1.46 unit $(b=1.46$; $\mathrm{SE}=$ $0.24 ; \mathrm{p}<0.001$ ).

Pendidikan dipengaruhi oleh usia ibu saat menikah. Setiap peningkatan satu unit usia ibu saat menikah (tahun) akan meningkatkan pendidikan ibu sebesar 0.01 unit ( $b=0.01 ; \mathrm{SE}<0.001 ; \mathrm{p}=0.002)$.

LILA ibu saat hamil dipengaruhi oleh usia ibu saat menikah. Setiap peningkatan satu unit usia ibu saat menikah (tahun) akan meningkatkan LILA ibu saat hamil 
$(\mathrm{cm})$ sebesar 0.12 unit $(\mathrm{b}=0.12 ; \mathrm{SE}=0.03$; $\mathrm{p}<0.001$ ).

Pendapatan keluarga dipengaruhi oleh usia ibu saat menikah. Setiap peningkatan satu unit usia ibu saat menikah (tahun) akan meningkatkan pendapatan keluarga (x Rp 100,000) sebesar 0.68 unit $(b=0.68 ; \mathrm{SE}=0.07 ; \mathrm{p}<0.001)$.
Stimulasi keluarga dipengaruhi oleh pendapatan keluarga. Setiap peningkatan satu unit pendapatan keluarga ( $\mathrm{x} \mathrm{Rp}$ 100,000) akan meningkatkan stimulasi keluarga sebesar 0.72 unit $(b=0.72 ; \mathrm{SE}=$ 0.26 ; $=0.005$ ).

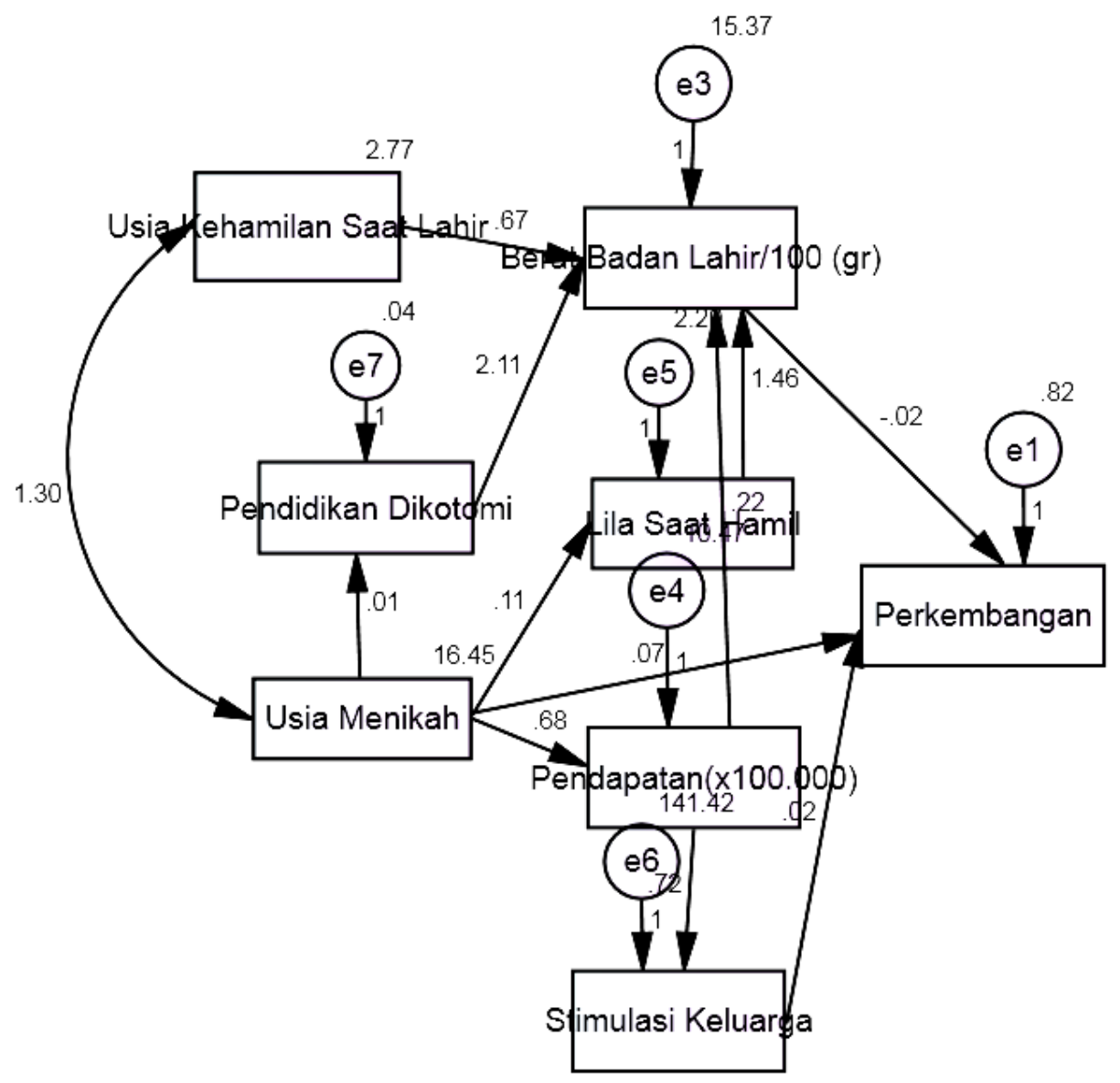

Gambar 2. Model struktural analisis jalur variabel perkembangan

Gambar 2 menunjukkan model struktural setelah dilakukan estimasi menggunakan IBM SPSS AMOS 20, sehingga didapatkan nilai seperti pada gambar tersebut. Indikator yang menunjukan kesesuaian model analisis jalur yaitu pada Tabel 5 juga menunjukkan adanya goodness of fit measure (pengukuran kecocokan model) bahwa didapatkan hasil fit index (indeks kecocokan) CMIN sebesar 10.62 dengan $\mathrm{p}=0.83$ $>0.05$; $\mathrm{NFI}=0.94 \geq 0.90 ; \mathrm{CFI}=1.00 \geq 0.95$; RMSEA $<0.001 \leq 0.08$ yang berarti model empirik tersebut memenuhi kriteria yang ditentukan dan dinyatakan sesuai dengan data empirik.

Melalui Tabel 5 dapat diketahui bahwa perkembangan batita dipengaruhi oleh stimulasi keluarga, usia ibu saat menikah dan berat badan bayi lahir.

Setiap peningkatan satu unit stimulasi keluarga akan meningkatkan perkembangan batita sebesar 0.02 unit $(b=0.02$; $\mathrm{SE}=0.01 ; \mathrm{p}<0.001)$. 
Journal of Maternal and Child Health (2017), 2(2): 137-149

https://doi.org/10.26911/thejmch.2017.02.02.05

Tabel 5. Hasil analisis jalur (path analysis) variabel perkembangan

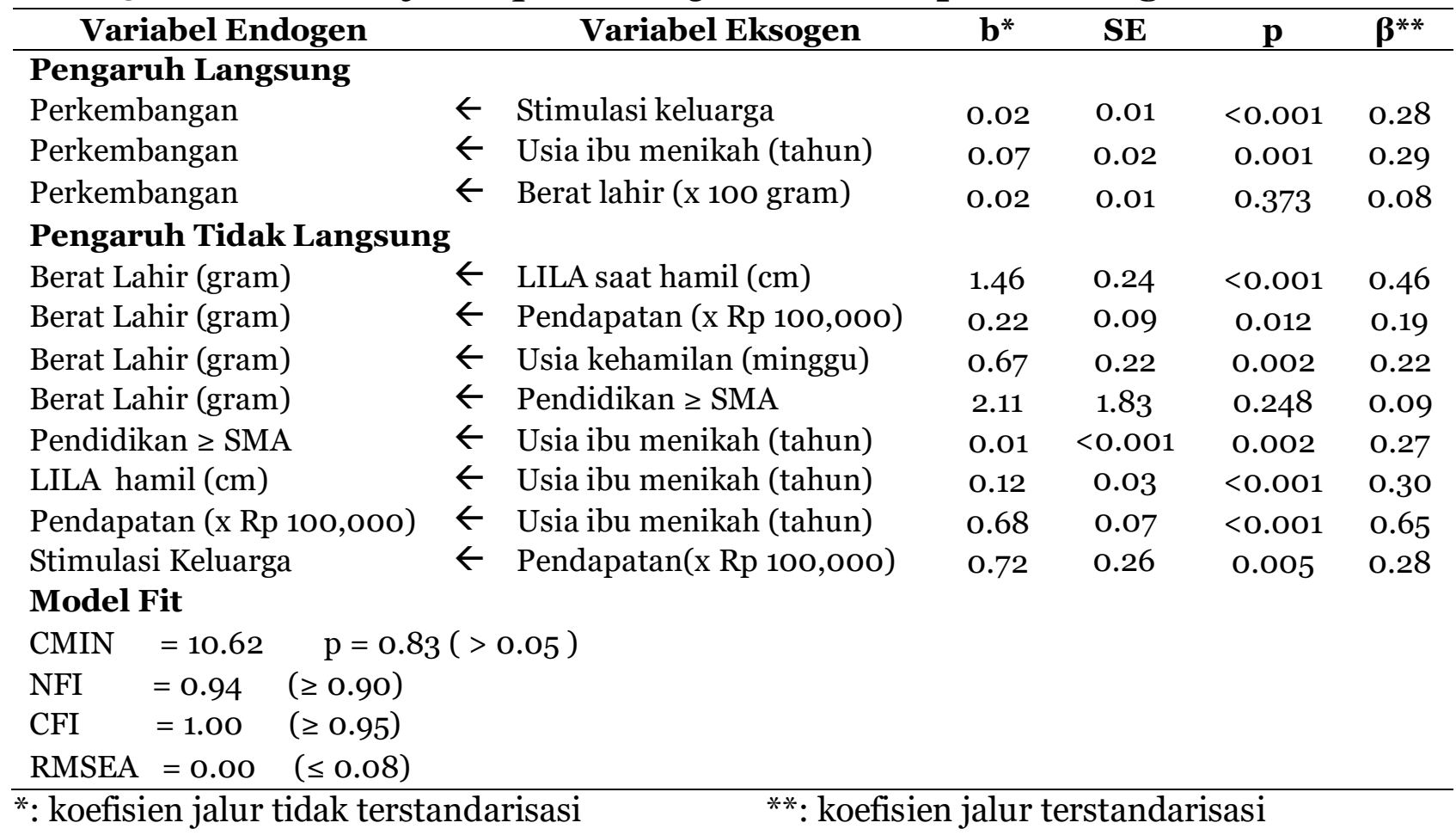

Setiap peningkatan usia ibu saat menikah (tahun) akan meningkatkan perkembangan batita sebesar 0.07 unit $(b=0.07 ; \mathrm{SE}=$ 0.02; $\mathrm{p}=0.001$ ).

Setiap peningkatan berat badan lahir bayi (x 100 gram) akan meningkatkan perkembangan batita sebesar 0.01 unit $(b=$ 0.01; $\mathrm{SE}<0.001 ; \mathrm{p}=0.373$ ).

Berat badan bayi lahir dipengaruhi oleh pendidikan ibu, usia kehamilan saat bayi lahir, pendapatan keluarga dan LILA ibu saat hamil.

Setiap peningkatan satu unit pendidikan ibu ( $\geq$ SMA) akan meningkatkan berat badan bayi lahir sebesar 2.11 unit $(b=$ 2.11; $\mathrm{SE}=1.83 ; \mathrm{p}=0.248$ ).

Setiap peningkatan usia kehamilan saat bayi lahir akan meningkatkan berat badan bayi lahir sebesar 0.67 unit $(b=0.67$; $\mathrm{SE}=0.22 ; \mathrm{p}=0.002$ ).

Setiap peningkatan pendapatan keluarga (x Rp 100,000) akan meningkatkan berat badan bayi lahir sebesar 2.11 unit $(b=$ 2.11; $\mathrm{SE}=1.83 ; \mathrm{p}=0.248$ ).
Setiap peningkatan LILA ibu saat hamil akan meningkatkan berat bayi lahir sebesar 1.46 unit $(b=1.46 ; \mathrm{SE}=0.24 ; \mathrm{p}<$ 0.001).

Pendidikan ibu dipengaruhi oleh usia ibu saat menikah. Setiap peningkatan satu unit usia ibu saat menikah (tahun) akan meningkatkan pendidikan ibu sebesar 0.01 unit ( $b=0.01 ; \mathrm{SE}<0.001 ; \mathrm{p}=0.002)$.

LILA ibu saat hamil dipengaruhi oleh usia ibu saat menikah. Setiap peningkatan satu unit usia ibu saat menikah akan meningkatkan LILA saat hamil sebesar 0.012 unit $(b=0.012 ; S E=0.03 ; p<0.001)$.

Pendapatan dipengaruhi oleh usia ibu menikah. Setiap peningkatan satu unit usia ibu menikah (tahun) akan meningkatkan pendapatan keluarga sebesar 0.68 unit $(b=$ 0.68; $\mathrm{SE}=0.07 ; \mathrm{p}=<0.001$ ).

Stimulasi keluarga dipengaruhi oleh pendapatan keluarga. Setiap peningkatan satu unit pendapatan keluarga (x Rp 100,000) akan meningkatkan stimulasi 
keluarga sebesar 0.72 unit $(b=0.72 ; \mathrm{SE}=$ $0.26 ; p=0.005)$.

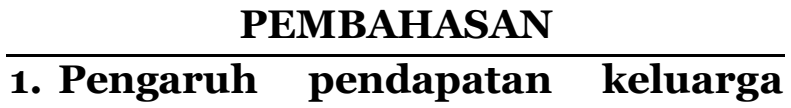 terhadap pertumbuhan batita}

Terdapat hubungan positif antara pendapatan keluarga dengan pertumbuhan batita dan secara statistik signifikan. Pernikahan usia dini dapat merampas hak anak untuk mendapatkan pendidikan yang layak, bermain dan memenuhi potensi dari pelaku pernikahan usia dini. Tingkat pendidikan yang rendah akan berdampak terhadap pemberdayaan ekonomi keluarga karena kesempatan untuk bekerja menjadi berkurang (Badan Pusat Statistik, 2016).

Status sosial ekonomi keluarga yang rendah dapat dilihat dari pendapatan keluarga yang rendah. Pendapatan yang rendah berpengaruh terhadap penyediaan makanan oleh keluarga terhadap anak. Ketersediaan makanan sehat untuk anak menjadi kurang terpenuhi. Pengentasan kemiskinan dapat meningkatkan status gizi anak, khusunya balita (Mohd et al., 2015).

Penelitian yang dilakukan oleh Fry dan Cohn (2010) mengemukakan bahwa status sosial ekonomi berpengaruh terhadap status kesehatan, dimana status ekonomi yang buruk akan berpengaruh pada kesehatan di kemudian hari. Salah satu indikator dari pertumbuhan adalah penilaian status gizi yang diperoleh dari pengukuran berat badan per umur $(\mathrm{BB} / \mathrm{U})$. Terdapat hubungan bermakna antara tingkat pendapatan keluarga dengan status gizi anak balita.

Rendahnya tingat pendidikan dan tingkat pendapatan menjadi penyebab ketersediaan pangan dalam keluarga tidak memadai. Keluarga dengan sosial ekonomi yang rendah rentan terhadap permasalahan makanan yang disebabkan karena daya beli rendah. Keluarga yang tidak mampu menyediakan makanan yang sehat untuk anaknya dapat memicu terjadinya permasalahan gizi dan penyakit infeksi. Kekurangan gizi yang disebabkan karena kemiskinan dapat menjadi suatu lingkaran kehidupan yang akan berulang ke generasi berikutnya (Black et al., 2008).

Berdasarkan uraian di atas dapat disimpulkan bahwa pendapatan keluarga yang cukup dapat memenuhi kebutuhan pangan keluarga sehingga menunjang status gizi keluarga terutama anak. Pendapatan keluarga yang mencukupi perlu ditunjang dengan pendidikan dan kemampuan keluarga dalam mengelola menu makanan untuk anak. Anak dengan konsumsi makanan sehat sesuai dengan kebutuhan dan umurnya akan terhidar dari permasalahan gizi sehingga status gizinya menjadi baik.

\section{Pengaruh berat badan lahir ter- hadap pertumbuhan batita}

Terdapat hubungan positif antara berat badan lahir dengan pertumbuhan batita dan secara statistik signifikan. Berat badan bayi merupakan salah satu indikator penting yang dapat digunakan untuk menentukan perkembangan fisik dan mental pada masa balita (Ehsanpour et al., 2012). Setiap tahun kejadian gizi kurang dan permasalahan gizi lainnya telah mendasari penyebab kematian anak di bawah usia lima tahun (Das et al., 2016).

Penentuan status gizi anak telah dimulai sejak sebelum kelahiran. Status gizi ibu sangat erat kaitannya dengan pertumbuhan janin di dalam rahim. Janin yang berkembang normal akan lahir dengan berat yang normal. Janin yang mengalami pertumbuhan terhambat akan memiliki risiko meningkat untuk lahir dengan kondisi BBLR. Selain status gizi ibu, status kesehatan ibu juga seperti ibu hamil yang mengalami penyakit hipertensi dan mengalami penyakit infeksi juga akan berpeng- 
Journal of Maternal and Child Health (2017), 2(2): 137-149

https://doi.org/10.26911/thejmch.2017.02.02.05

aruh terhadap pertumbuhan janin intrauterine (Jay et al., 2016).

Penelitian yang dilakukan oleh Rahman et al., (2016) menyatakan bahwa terdapat hubungan yang signifikan antara BBLR dengan status gizi balita. Penelitian yang dilakukan secara retrospektif ini mengemukakan bahwa sebagian besar anak dengan masalah gizi mempunyai riwayat kelahiran dengan kondisi BBLR. Anak yang lahir BBLR akan cenderung kurus pada pertumbuhan berikutnya dan angka kesakitan semakin meningkat.

Penelitian yang dilakukan oleh Ehsanpour et al., (2012) memberikan informasi penting terkait pertumbuhan bayi dengan riwayat berat lahir normal, BBLR dan BBLSR. Menurut perhitungan dengan menggunakan persentil National Center for Health Statistics /NCHS menunjukkan bahwa bayi dengan riwayat berat lahir di bawah normal akan memiliki pertumbuhan berat, panjang dan lingkar kepala yang lebih rendah dibandingkan bayi dengan riwayat berat lahir normal. Berdasarkan uraian tersebut, hasil penelitian ini sesuai dengan penelitian terdahulu yaitu berat badan lahir mempengaruhi pertumbuhan anak batita. Hal tersebut berkaitan dengan riwayat bayi sebelum lahir yang ada hubungannya dengan maslah gizi.

3. Pengaruh stimulasi keluarga terhadap perkembangan batita

Terdapat hubungan positif antara stimulasi keluarga terhadap perkembangan batita dan secara statistik signifikan. Masa anak anak merupakan fase perkembangan yang paling penting. Pendidikan ibu, status sosial ekonomi dan stimulasi keluarga berpengaruh terhadap perkembangan anak (Barros, 2016).

Berdasarkan penelitian yang dilakukan oleh Warsito et al., (2016) menyebutkan bahwa perkembangan kognitif anak selain dipengaruhi oleh status nutrisi, ada hal lain yang sangat penting dilakukan untuk perkembangan anak, yaitu stimulasi oleh keluarga. Nutrisi yang baik dapat bermanfaat untuk anak dalam menerima segala bentuk stimulasi yang diberikan. Perkembangan yang optimal tidak akan tercapai hanya dengan status nutrisi yang baik tanpa adanya rangsangan/ stimulasi yang tepat dan rutin dilakukan.

Berdasarkan penelitian yang dilakukan oleh Innike dan Purwanti (2014) menyebutkan bahwa stimulasi dengan metode tertentu dapat mempengaruhi perkembangan anak. Bentuk stimulasi menggunakan gambar lebih baik dibandingkan menggunakan tulisan. Anak yang sering diberikan stimulasi oleh orangtua cenderung mengalami perkembangan yang sesuai dibanding anak yang tidak mendapatkan stimulasi. Perkembangan anak dipengaruhi oleh banyak faktor, diantaranya faktor genetik dan faktor lingkungan.

Perkembangan pada masa anak anak merupakan suatu kunci bagi keberlangsungan kehidupan generasi dan kemajuan sebuah bangsa. Pembelajaran pada masa anak - anak dapat digunakan sebagai dasar kesejahteraan di masa dewasa. Pada tahun pertama kehidupan adalah masa kritis terhadap perkembangan anak. Diperlukan upaya yang optimal untuk kelangsungan tumbuh kembangnya. Orangtua/ keluarga terdekat harus sesering mungkin memberikan rangsangan atau stimulasi. Harapannya tidak ada gangguan perkembangan pada anak (McCoy et al., 2016).

\section{Pengaruh usia ibu menikah ter- hadap perkembangan batita}

Terdapat hubungan positif antara usia menikah dengan perkembangan anak batita dan secara statistik signifikan. Pernikahan usia dini dapat merampas hak anak untuk mendapatkan pendidikan yang layak, bermain dan memenuhi potensi dari pelaku pernikahan usia dini. Tingkat pendidikan 
rendah akan berdampak terhadap pemberdayaan ekonomi keluarga karena kesempatan untuk bekerja menjadi berkurang (Badan Pusat Statistik, 2016).

Berdasarkan hasil penelitian Fry dan Cohn (2010) menyebutkan bahwa saat ini tren kontribusi gender terhadap pekerjaan telah mengalami perubahan. Dahulu perempuan lebih banyak di rumah dan lakilaki bekerja, sehingga kondisi ekonomi keluarga sangat bergantung terhadap laki laki. Kondisi tersebut berbeda dengan saat ini dimana perempuan banyak yang bekerja dan dapat meningkatkan kesejahteraan keluarga. Kesempatan perempuan untuk berkerja salah satunya dipengaruhi oleh pendidikan. Perempuan dengan pendidikan yang tinggi dapat memperoleh kesempatan untuk mendapatkan pekerjaan dengan penghasilan yang lebih tinggi.

Wanita yang saat menikah dan hamil tidak berada pada rentang usia reproduksi matang, akan berdampak pada proses kehamilannya. Terdapat berbagai permasalahan pada saat hamil, seperti, anemia, organ reproduksi yang belum matang, dan risiko melahirkan BBLR meningkat. Menjadi orangtua dengan usia yang relatif masih muda akan berdampak terhadap pola asuh anak. Ketrampilan dalam memberikan pengasuhan terhadap anak masih sangat terbatas, ditambah dengan beban ganda yang harus ditanggung sehingga mempengaruhi perkembangan anak (UNICEF, 2014).

Berdasarkan penelitian yang dilakukan oleh Sutcliffe et al., (2012) memberikan informasi bahwa anak yang berasal daribu yang berusi muda cenderung lebih banyak memiliki gangguan dalam perkembangan bahasa. Perkembangan sosial emosional anak dari ibu yang berusia muda juga lebih banyak mengalami permasalahan. Hal tersebut berkaitan dengan kemampuan ibu dalam melakukan interaksi sosial terhadap lingkungan yang secara tidak langsung akan mempengaruhi pola asuh dan berdampak terhadap perkembangan anak. Usia ibu juga akan berpengaruh terhadap status kesehatan anak. Ibu muda kurang memberikan perawatan dan pemenuhan kebutuhan kesehatan yang berkualitas sehingga akan berdampak juga terhadap status kesehatan anak. Anak yang lahir dari ibu yang berusia muda dapat mengalami perkembangan yang sesuai jika keluarga atau orang terdekat mampu melakukan stimulasi dengan baik.

\section{Pengaruh berat badan lahir ter- hadap perkembangan batita}

Terdapat hubungan positif antara berat badan lahir dengan perkembangan batita dan secara statistik tidak signifikan. Anak yang lahir dengan riwayat berat badan lahir rendah memiliki kecenderungan untuk mengalami masalah perkembangan di kemudian hari. Hal tersebut disebabkan karena bayi dengan berat badan lahir rendah lebih rentan terhadap penyakit infeksi sehingga akan berdampak terhadap proses tumbuh kembangnya (Scharf et al., 2016).

Berat badan lahir rendah, selain dapat memicu terjadinya kematian karena komplikasi juga dapat menyebabkan terhambatnya pertumbuhan pada awal masa balita (UNICEF, 2010).

Terdapat beberapa hal yang dapat berperan terhadap perkembangan anak, seperti gizi yang cukup, perawatan berupa kasih sayang dan kesempatan belajar anak yang memadai. Pemenuhan kebutuhan asih asah dan asuh di tahun pertama kehidupan akan mempengaruhi perkembangan anak di tahun berikutnya. Anak yang mendapatkan ASI ekslusif dan lingkungan yang mendukung tumbuh kembangnya sangat berpengaruh terhadap kelangsungan hidup anak (Pem, 2015). 
Berdasarkan penelitian yang dilakukan oleh Linsell et al., (2015) bahwa perkembangan batita sangat dipengaruhi oleh kondisi berat badan pada saat lahir. Anak yang lahir dengan BBLR berisiko untuk mengalami permasalahan dalam perkembangannya. Faktor eksternal seperti lingkungan dan stimulasi serta pola asuh dapat mengubah kondisi tersebut. Artinya, meskipun lahir dengan BBLR anak masih mempunyai kesempatan untuk tumbuh dan berkembang secara optimal jika faktor eksternal seperti stimulasi dan pola asuh diberikan secara maksimal.

Penelitian ini sesuai dengan penelitian terdahulu yaitu anak yang lahir dengan berat badan rendah atau dibawah normal masih mempunyai kesempatan untuk berkembang secara normal sesuai dengan umur jika orang terdekat dapat memberikan stimulai maupun perawatan yang baik.

Pertumbuhan anak batita dipengaruhi oleh pendapatan keluarga dan berat badan lahir. Berat badan lahir dipengaruhi oleh pendidikan, usia bayi saat lahir dan pendapatan keluarga. Pendapatan keluarga dipengaruhi oleh usia menikah. LILA saat hamil dipengaruhi oleh usia ibu saat menikah. Pendidikan dipengaruhi oleh usia ibu saat menikah. Perkembangan anak batita dipengaruhi oleh usia ibu saat menikah, stimulasi keluarga dan berat badan lahir.

\begin{tabular}{l}
\hline REFERENCE \\
\hline Badan Pusat Statistik (2016). Kemajuan \\
Yang Tertunda: Analisis Data Perka- \\
winan Usia Anak di Indonesia. Ja- \\
karta. Badan Pusat Statistik.
\end{tabular}

Barros AJ, Matijasevich A, Santos IS, Halpern R (2010). Child development in a birth cohort: effect of child stimulation is stronger in less educated mothers. International Journal of Epidemiology, 39(1), 285-294.
Black ER (2013). Maternal and Child Undernutrition and Overweight in Low-Income and Middle-Income Countries. The Lancet.

Das JK, Salam RA, Imdad A. Infant and Young Child Growth. In: Black RE, Laxminarayan $\mathrm{R}$, Temmerman $\mathrm{M}$ (2016). Reproductive, Maternal, Newborn, and Child Health: Disease Control Priorities, Third Edition (Volume 2). The International Bank for Reconstruction and Development/ The World Bank. Chapter 12.

Depkes RI (2006). Pedoman Pelaksanaan Stimulasi, Deteksi dan Intervensi Dini Tumbuh Kembang. Depkes RI

Dinas Kesehatan Kota Kediri (2016). Profil Kesehatan Kota Kediri Tahun 2015. Kota Kediri: Dinas Kesehatan Kota Kediri.

Edward (2012). The health and development of children born to older mothers in the United Kingdom: observational study using longitudinal cohort data BMJ 345.

Ehsanpour S, Hemmati E, Abdeyazdan Z (2012). Comparison of neonatal growth in normal, low and very low birth weights until 18 months. Iranian Journal of Nursing and Midwifery Research, 17(2): S131-S136.

Fry R, Cohn D (2010). Women, Men and the New Economics of Marriage.Pew research center social and demographic trends.

Innike, Asri P (2014). Pengaruh Pelatihan Stimulasi Keluarga oleh Ibu Dalam Bnetuk Tulisan dengan Gambar terhadap Perkembangan Anak Usia Kurang dari 3 Tahun. Sari Pediatri. 1(4).

Jai KD, Rehana AS, Aamer I, Zulfiqar AB (2016). Infant and Young Child Growth. The World Bank. Chapter 12. 
Kemenkes RI (2014). Infodatin: Kondisi Pencapaian Program Kesehatan Anak Indonesia. Jakarta.

Linsell L, Malouf R, Morris J, Kurinczuk JJ, Marlow N (2015). Prognostic Factors for Poor Cognitive Development in Children Born Very Preterm or With Very Low Birth WeightA Systematic Review. JAMA Pediatr 169(12):11621172.

McCoy DC, Peet ED, Ezzati M, Danaei G, Black MM, Sudfeld CR, Fink G (2016). Early Childhood Developmental Status in Low- and Middle-Income Countries: National, Regional, and Global Prevalence Estimates Using Predictive Modeling. PLoS Medicine, 13(6).

Mena K (2016). What Are the Effects of Teenage Pregnancy?. www.healthline.com. Diakses: 15 Oktober 2016.

Mohd SZ, Lin KG, Sariman S, Lee HS, Siew, CY, Mohd BN, Mohamad M (2015). The relationship between household income and dietary intakes of 1-10 year old urban Malaysian. Nutrition Research and Practice, 9(3): 278-287.

Murti B (2013). Desain dan ukuran sampel untuk penelitian kuantitatif dan kualitatif di bidang kesehatan. Yogyakarta: Gajah Mada University Press.

Pem D (2015). Factors Affecting Early Childhood Growth and Development Golden 1000 Days. Jornal of advanced practices in nursing 1(1): 1-7.
Rahman MS, Howlader T, Masud MS, Rahman ML (2016). Association of Low-Birth Weight with Malnutrition in Children under Five Years in Bangladesh: Do Mother's Education, SocioEconomic Status, and Birth Interval Matter? Plos One, 11(6).

Scharf RJ, Stroustrup A, Conaway MR (2016). Growth and development in children born very low birthweight Archives of Disease in Childhood Fetal and Neonatal Edition 101:F433F438.

UNICEF (2010). Low Birth Weight Country Regional and Global Estimates.New York : Unicef.

(2014). Ending Child Marriage. https://www.unicef.org/media/files/ Child-marriage.pdf.

(2016). Child marriage. Child protection from violence, exploitation and abuse.

Warsito O, Khomsan A, Hernawati N, Anwar F (2012). Relationship between nutritional status, psychosocial stimulation, and cognitive development in preschool children in Indonesia. Nutrition Research and Practice, 6(5), 451-457. 